\title{
PELAKSANAAN PENDIDIKAN DAN PELATIHAN PEGAWAI APARATUR SIPIL NEGARA DI LINGKUNGAN SEKRETARIAT DAERAH KOTA PEKANBARU
}

\author{
Fara Merian sari \\ Universitas Lancang Kuning \\ e-mail: fara.unilak@unilak.ac.id
}

\begin{abstract}
The purpose of this research is to know the Implementation of Education and Training of State Apparatus of State Apparatus (ASN) in Pekanbaru City Regional Secretariat Year 2016 and Barriers Factor in Implementation of Education and Training of State Apparatus (ASN) in Pekanbaru City Regional Secretariat 2016. Based on the results of research on the implementation of Education and Training Method On The Job Site conducted in the Regional Secretariat of Pekanbaru In practice used the method of Debriefing, Job Rotation, Apprenticeship and Assignment While using methods of Information Presentation Techniques and Simulation Techniques, As for factors that become obstacles in the implementation of education and training (Training) Employees of State Civil Apparatus in the Regional Secretariat of Pekanbaru (1) It is not easy to obtain experienced staff from within because of the limited ability or time. (2) The number of participants must meet a favorable ratio. (3) The difficulty of arranging study time, meaning many things to consider. (4) experienced staff (senior) lack of encouragement or encouragement to new employees, so that when the learning begins the atmosphere is not conducive and the employees tend not to be passionate to follow the Training. (5) Participants may not directly apply the knowledge or skills gained from the exercise. (6) The cost is relatively larger than the cost if the exercise is held by the agency itself.
\end{abstract}

Keywords: Implementation, Training, ASN.

\section{Abstrak}

Tujuan penelitian ini adalah untuk mengetahui Pelaksanaan Pendidikan danPelatihan (Diklat) Aparatur Sipil Negara (ASN) di lingkungan Sekretariat Daerah Kota Pekanbaru Tahun 2016 dan Faktor Hambatan dalam Pelaksanaan Pendidikan dan Pelatihan (Diklat) Aparatur Sipil Negara (ASN) di Lingkungan Sekretariat Daerah Kota Pekanbaru Tahun 2016. Berdasarkan hasil penelitian Pelaksanaan Pendidikan dan Pelatihan Metode On The Job Site yang dilakukan di Lingkungan Sekretariat Daerah Kota Pekanbaru Dalam prakteknya digunakan metode Pembekalan, Rotasi Jabatan, Magang dan Penugasan Sementara menggunakan metode Teknik Presentasi Informasi dan Teknik Simulasi, Adapun faktor-faktor yang menjadi kendala dalam pelaksanaan pendidikan dan pelatihan (Diklat) Pegawai Aparatur Sipil Negara di Lingkungan Sekretariat Daerah Kota Pekanbaru (1) Tidak mudah memperoleh pegawai yang berpengalaman dari dalam karena adanya keterbatasan kemampuan atau waktu. (2) Jumlah peserta harus memenuhi rasio yang menguntungkan. (3) Sulitnya mengatur waktu belajar, artinya banyak hal-hal yang harus dipertimbangkan. (4) pegawai yang berpengalaman (senior) kurang memberikan semangat atau dorongan kepada pegawai baru, sehingga saat pembelajaran dimulai suasana tidak kondusif dan para pegawai cenderung tidak bergairah untuk mengikuti Diklat. (5) Peserta adakalanya tidak dapat langsung menerapkan pengetahuan atau keterampilan yang diperoleh dari latihan. (6) Biaya yang dikeluarkan relatif lebih besar dari biaya apabila latihan itu diselenggarakan sendiri oleh instansi.

Kata Kunci: Pelaksanaan, Pelatihan, Diklat, ASN. 


\section{PENDAHULUAN}

Pegawai sebagai Aparatur Sipil Negara (ASN) memiliki kedudukan dan peran yang sangat penting dalam penyelenggaraan fungsi pemerintahan. Arti penting dari ASN sebagai sarana pemerintahan adalah jika dikaitkan dengan pengisian jabatan pemerintahan, yang diisi oleh Aparatur Sipil Negara. Kedudukan Aparatur Sipil Negara mempunyai peran penting dalam menyelenggarakan fungsi pemerintahan di suatu negara dalam rangka mencapai tujuan nasional atau dengan kata lain dalam rangka usaha untuk mencapai tujuan nasional, diperlukan adanya Aparatur Sipil Negara sebagai unsur Aparatur Negara, Abdi Negara, dan Abdi masyarakat yang penuh kesetian dan ketaatan kepada Pancasila, Undang-Undang Dasar 1945, Negara dan Pemerintah serta bersatu padu, dan sadar akan tanggung jawabnya untuk menyelenggarakan tugas pemerintahan dan pembangunan (Tjandra, $2013: 173$ ).

Berdasarkan Undang-Undang Nomor 5 Tahun 2014 tentang Aparatur Sipil Negara pasal 1 ayat 1, menyatakan bahwa "Aparatur Sipil Negara yang selanjutnya disingkatASN adalah profesi bagi pegawai negeri sipil danpegawai pemerintah dengan perjanjian kerja yangbekerja pada instansi pemerintah".

Kemudian ayat 2 menyatakan bahwa "Pegawai Aparatur Sipil Negara yang selanjutnya disebut Pegawai ASN adalah pegawai negeri sipil dan pegawai pemerintah dengan perjanjian kerja yang diangkat oleh pejabat pembina kepegawaian dan diserahi tugas dalam suatu jabatan pemerintahan atau diserahi tugas negara lainnya dan digaji berdasarkan peraturan perundang-undangan.

Berdasarkan penjelasan Undang-UndangNomor 5 Tahun 2014 diatas jelaslah bahwa pegawai negeri sipil sebagai Aparatur Sipil Negara yang selanjutnya disebut Pegawai ASN hendaklah memenuhi persyaratan untuk memegang suatu jabatan. Oleh karena itu terhadap pegawai negeri perlu adanya peningkatan sumber daya agar pegawai tersebut memiliki kemampuan dalam pelaksanaan tugas-tugasnya secara profesional dan bertanggungjawab dalam melaksanakan tugas-tugas pemerintahan dan pembangunan serta bersih dan bebas dari korupsi, kolusi dan nepotisme. Salah satu peningkatan sumber daya pegawai negeri adalah melalui pengembangan dan pembinaan dengan meningkatkan kemampuan profesionalisme pegawai dalam rangka memberikan pelayanan yang baik kepada masyarakat.

Guna mencapai hal tersebut, maka perlu pengembangan Sumber Daya Manusia (SDM) antara lain dapat dilakukan dengan memberikan pendidikan dan pelatihan yang dapat dipandang sebagai salah satu bentuk investasi bagi organisasi. Oleh karena itu, setiap organisasi atau instansi yang ingin berkembang, pendidikan dan pelatihan bagi pegawainya harus memperoleh perhatian besar. Untuk itu, maka kemampuan sumberdaya manusia atau pegawaisebagai Aparatur Sipil Negara pada suatu organisasi harus terus-menerus ditingkatkan seiring dengan kemajuan, perkembangan dan tuntutan organisasi.

Untuk mencapai hasil yang diharapkan dalam suatu organisasi atau instansi, para pegawai sebagai Aparatur Sipil Negara perlu mendapatkan program pendidikan dan pelatihan yang memadai untuk jabatannya sehingga para pegawai menjadi terampil dalam melaksanakan pekerjaannya. Dalam meningkatkan mutu pegawai melalui pelaksanaan pendidikan dan pelatihan harus dipersiapkan dengan baik agar tercapai hasil yang memuaskan, karena kecakapan pegawai sangat diperlukan dalam sebuah instansi, sehingga dengan adanya program tersebut dapat membantu meningkatkan kemampuan dan keterampilan pegawai. Pengembangan pegawai sebagai Aparatur Sipil Negara juga dirancang untuk memperoleh pegawai-pegawai yang mampu berprestasi dan fleksibel dalam suatu instansi dan geraknya ke masa depan.

Aparatur Sipil Negara (ASN) sebagai unsur utama aparatur negara yang mempunyai peranan, dalam menentukan keberhasilan penyelenggaraan pemerintahan dan pembangunan. Sesuai dengan tuntutan nasional dan tantangan global, untuk mewujudkan kepemerintahan yang baik diperlukan sumber daya manusia sebagai aparatur yang memiliki kompetensi dalam penyelenggaraan negara dan pembangunan. Untuk menciptakan sumber daya manusia sebagai Aparatur Negara yang memiliki kompetensi tersebut maka diperlukan peningkatan mutu sehingga menjadi pegawai yang professional dan memiliki wawasan luas sebagai Pegawai Negeri atau Aparatur Sipil Negara. 
Oleh sebab itu, suatu instansi harus dapat meningkatkan kualitas sumber daya manusianya. Untuk meningkatkan kualitas atau kemampuan-kemampuan pegawai tersebut, salah satunya dapat dilakukan melalui Pendidikan dan Pelatihan (Diklat). Karena Pendidikan dan Pelatihan merupakan bagian tidak terpisahkan dari usaha pembinaan Pegawai sebagaia Aparatur Sipil Negara secara menyeluruh dan berkesinambungan.

Berdasarkan Peraturan Pemerintah Nomor 18 Tahun 2016 tentang Perangkat Daerah Sekretariat Daerah kabupaten/kota sebagaimana dimaksud pada ayat (1) dipimpin oleh Sekretaris Daerah Kabupaten/Kota dan bertanggung jawab kepada Bupati/Walikota. Sekretariat Daerah Kabupaten/Kota mempunyai tugas membantu Bupati/Walikota dalam penyusunan kebijakan dan pengoordinasian administratif terhadap pelaksanaan tugas Perangkat Daerah serta pelayanan administratif.

Dalam Peraturan Pemerintah Nomor 18 Tahun 2016 tentang Perangkat Daerah Sekretariat Daerah Kabupaten/Kota mempunyai tugas dan fungsinya sebagai berikut:

1. Pengoordinasian penyusunan kebijakan Daerah;

2. Pengoordinasian pelaksanaan tugas satuan kerja Perangkat Daerah;

3. Pemantauan dan evaluasi pelaksanaan kebijakan Daerah;

4. Pelayanan administratif dan pembinaan aparatur sipil negara pada instansi Daerah; dan

5. Pelaksanaan fungsi lain yang diberikan oleh bupati/wali kota terkait dengan tugas dan fungsinya.

Pentingnya pendidikan dan pelatihan bukanlah semata-mata bagi pegawai yang bersangkutan, tetapi juga keuntungan organisasi. Karena dengan meningkatnya kemampuan atau keterampilan para pegawai, dapat meningkatkan produktivitas kerja para pegawai. Produktivitas kerja meningkat berarti organisasi yang bersangkutan akan memperoleh keuntungan. Pendidikan dan Pelatihan juga merupakan upaya dalam mengembangkan kemampuan intelektual dan kepribadian pegawai. Oleh karena itu setiap organisasi atau instansi yang ingin berkembang, Pendidikan dan Pelatihan pegawainya harus memperoleh perhatian yang lebih besar sehingga dapat meningkatkan kualitas pegawainya.

Sekretariat Daerah adalah unsur pembantu pimpinan pemerintah daerah, yang dipimpin oleh sekretaris daerah. Sekretaris daerah bertugas membantu kepala daerah dalam menyusun kebijakan dan mengkoordinasikan dinas daerah dan lembaga teknis daerah. Dalam pelaksanaan tugas dan kewajibannya, sekretaris daerah bertanggung jawab kepada Kepala Daerah. Sekretaris Daerah diangkat dari Pegawai Negeri Sipil (PNS) yang memenuhi persyaratan. Sekretaris Daerah karena kedudukannya sebagai pembina PNS di daerahnya. Sekretaris Daerah dapat disebut jabatan paling puncak dalam pola karier PNS di Daerah.

Sekretariat Daerah mempunyai peranan penting dalam mengawal proses perubahan dengan cara melakukan gerakan reformasi birokrasi. Karena itu sekda perlu menata birokrasi dengan mewujudkan pelayanan prima, supaya harapan masyarakat untuk hidup lebih baik tercapai, dan mereka bisa merasakan keberadaan pemerintah yang berdaya guna, bersih dan bertanggung jawab. Sekretariat daerah langsung berkoordinasi dengan walikota kota Pekanbaru dalam mengatur pelaksanaan tugas seluruh dinas daerah dan lembaga teknis daerah serta melakukan pemantauan dan pembinaan aparatur pemerintahab daerah. Oleh karena itu peran sekretariat daerah sangat dibutuhkan dalam membantu pemerintah daerah untuk mewujudkan pemerintahan yang bersih dan tertata.

Berdasarkan data yang diperoleh Aparatur Sipil Negara (ASN) yang mengikut pelaksanaan Diklat dilingkungan Sekretariat Daerah Kota Pekanbaru. Dari data dalam tabel berikut dapat dilihat bahwa Pendidikan dan Pelatihan (Diklat) untuk Aparatur Sipil Negara (ASN) dilingkungan Sekretariat Daerah Kota Pekanbaru yang telah mengikuti Pendidikan dan Pelatihan (Diklat) Prajabatan pada tahun 20122016: 
Tabel 1.1

Data Pegawai Negeri Sipil Dilingkungan Sekretariat DaerahKota Pekanbaru Yang Sudah Mengikuti Diklat Tahun 2016

\begin{tabular}{|c|c|c|}
\hline No. & Jenis Diklat & Jumlah \\
\hline 1. & Diklat Kepemimpinan & 5 Orang \\
\hline 2. & Diklat Fungsional & 9 Orang \\
\hline 3. & Diklat Teknis & 23 Orang \\
\hline \multicolumn{2}{|c|}{ Jumlah } & 37Orang \\
\hline
\end{tabular}

Sumber : Badan Kepegawaian Daerah Kota Pekanbaru, 2016.

Berdasarkan tabel di atas Pegawai Negeri Sipil di Lingkungan Sekretariat Daerah Kota Pekanbaru yang sudah mengikuti Diklat tahun 2016 adalah sebanyak 37 orang, diklat dalam jabatan dilaksanakan untuk mengembangkan pengetahuan, keterampilan, dan sikap Pegawai Negeri Sipil (PNS) agar dapat melaksanakan tugas-tugas pemerintah dan pembangunan dengan sebaik-baiknya. Sedangkan jumlah pegawai di Sekretariat Daerah Kota Pekanbaru menurut golongan adalah sebagai berikut:

Tabel 2.2

Jumlah Pegawai Sekretariat Daerah Kota Pekanbaru

\begin{tabular}{|l|l|l|}
\hline No & Nama Bagian & Jumlah \\
\hline 1 & Bagian Umum & 55 \\
\hline 2 & Bagian Humas & 13 \\
\hline 3 & Bagian Keuangan \& Aset & 13 \\
\hline 4 & Bagian Protokol & 10 \\
\hline 5 & Bagian Kerja Sama & 8 \\
\hline 6 & Bagian Adm. Pembangunan dan PDE & 15 \\
\hline 7 & Bagian Adm. Perekonomian \& SDA & 10 \\
\hline 8 & Bagian Organisasi dan Tata Laksana & 10 \\
\hline 9 & Bagian Hukum & 8 \\
\hline 10 & Bagian Adm. Kesejahteraan Rakyat & 12 \\
\hline 11 & Pemerintahan Umum & 12 \\
\hline Jumlah & & $\mathbf{1 6 6}$ \\
\hline
\end{tabular}

Sumber : Sekretariat Daerah Kota Pekanbaru

Berdasarkan tabel di atas jumlah pegawai yang ada di Sekretariat Daerah Kota Pekanbaru berjumlah 166 orang, melihat pentingnya sumber daya manusia dalam suatu organisasi atau instansi, maka tidak berlebihan jika dikatakan bahwa manusia adalah aset yang paling penting dan berdampak langsung pada organisasi atau instansi, dibandingkan dengan sumber daya-sumber daya lainnya. Karena manusia memberikan tenaga, bakat, kreativitas, dan usaha mereka kepada organisasi atau instansi tersebut.

Aparatur Sipil Negara berkedudukan sebagai unsur aparatur negara yang bertugas untuk memberikan pelayanan kepada masyarakat secara profesional, jujur, adil, dan merata dalam penyelenggaraan tugas negara, pemerintahan dan pembangunan.

Sesuai dengan tuntutan nasional dan tantangan global untuk mewujudkan kepemerintahan yang baik diperlukan sumber daya manusia aparatur yang memiliki kompetensi jabatan dalam penyelenggaraan negara dan pembangunan. Untuk menciptakan sumber daya manusia aparatur yang memiliki kompetensi tersebut diperlukan mutu profesionalisme, sikap pengabdian dan kesetiaan pada perjuangan bangsa dan negara, semangat kesatuan dan persatuan, dan pengembangan wawasan Pegawai Negeri Sipil/ Aparatur Sipil Negara melalui Pendidikan dan Pelatihan Jabatan yang merupakan bagian tidak terpisah dari usaha pembinaan Pegawai Negeri Sipil/Aparatur Sipil Negara secara menyeluruh. 
Dasar hukum Diklat bagi Pegawai Negeri Sipil/Aparatur Sipil Negara adalah Peraturan Pemerintah Nomor 101 Tahun 2000 tentang Pendidikan dan Pelatihan Jabatan Pegawai Negeri Sipil. Berdasarkan Peraturan Pemerintah No. 101 tahun 2000 tentang Pendidikan dan Pelatihan Jabatan Pegawai Negeri Sipil, menekankan pada tujuan :

1. Meningkatkan pengetahuan, keahlian, keterampilan, dan sikap untuk dapat melaksanakan tugas jabatan secara profesional dengan dilandasi kepribadian dan etika Pegawai Negeri Sipil sesuai dengan kebutuhan instansi

2. Menciptakan aparatur yang mampu berperan sebagai pembaharu dan perekat persatuan dan kesatuan bangsa

3. Memantapkan sikap dan semangat pengabdian yang berorientasi pada pelayanan, pengayoman, dan pemberdayaan masyarakat

4. Menciptakan kesamaan visi dan dinamika pola pikir dalam melaksanakan tugas pemerintahan umum dan pembangunan demi terwujudnya kepemerintahan yang baik.

Sedangkan, sasaran Diklat bagi PNS/ASN adalah terwujudnya PNS/ASN yang memiliki kompetensi yang sesuai dengan persyaratan jabatan masing-masing serta fungsi Diklat meliputi dua fungsi sekaligus, yaitu fungsi pendidikan dan fungsi pelatihan yang merupakan satu kesatuan yang tidak terpisahkan. Diklat Prajabatan merupakan Diklat pembentukan awal bagi para Calon Pegawai Negeri Sipil diatur dalam Perka LAN No. 10, 15, dan 16 tahun 2015 dimana diklat ini ditujukan untuk membangun integritas moral, kejujuran, semangat dan motivasi nasionalisme dan kebangsaan, karakter kepribadian yang unggul dan bertanggungjawab, dan memperkuat profesionalisme serta kompetensi bidang.

Adapun identifikasi masalah dalam penelitian ini dalam pelaksanaan pendidikan dan pelatihan dilingkungan Sekretariat Daerah Kota Pekanbaru antara lain :

1. Sulitnya mengatur waktu belajar antara pegawai yang lebih berpengalaman (senior) dengan pegawai baru untuk melakukan pelatihan dalam suatu bidang pekerjaan, hal ini dikarenakan pegawai yang berpengalaman (senior) masih sibuk dengan tugas yang dimilikinya sehingga masih sulit untuk mengatur waktu belajar, artinya banyak hal-hal yang harus dipertimbangkan.

2. Peserta adakalanya tidak dapat langsung menerapkan pengetahuan atau keterampilan yang diperoleh dari latihan, hal ini dapat melihat dari sisi kualitas pegawainya ketika sudah diberikan latihan sebaiknya pegawai dapat mempraktikannya kedalam pekerjaannya, jika masih belum bisa menerapkannya maka akan diadakan latihan selanjutnya.

Untuk meningkatkan kemampuan/kompetensi Aparatur Sipil Negara (ASN) dilingkungan Pemerintah Kota Pekanbaru khususnya pada Sekretariat Daerah Kota Pekanbaru dalam hal ini dengan melakukan pengembangan pegawai yaitu dengan mengadakan Pendidikan dan Pelatihan Jabatan yang mengarah pada sikap dan pengabdian yang berorientasi pada Kepentingan Masyarakat, Bangsa dan Negara sehingga dapat meningkatkan efisiensi, efektifitas dan kualitas pelaksanaan tugas yang dilakukan dengan semangat kerjasama dan tanggung jawab, sesuai dengan lingkungan kerja dan organisasinya.

Pendidikan Aparatur Sipil Negara (ASN) ialah pendidikan yang dilakukan bagi ASN untuk meningkatkan kepribadian, pengetahuan, kemampuannya sesuai dengan ketentuan persyaratan jabatan dan pekerjaannya sebagai ASN. Adapun pelatihan ASN ialah bagian dari pendidikan yang dilakukan bagi Pegawai Negri sebagai Aparatur Sipil Negara (ASN) untuk meningkatkan pengetahuan dan ketrampilannya sesuai dengan tuntutan persyaratannya sebagai Aparatur Sipil Negara (ASN).

Metode Diklat yang digunakan dalam pelaksanaan diklat di lingkungan Sekretariat Daerah Kota Pekanbaru adalah metode yang sesuai dengan tujuan dan program diklat bagi orang dewasa (andradogi). Diklat bagi orang dewasa (andradogi) adalah proses pendidikan membantu orang dewasa menemukan penemuan-penemuan dari bidang ilmu pengetahuan berhubungan dengan latar belakang sosial dan situasi 
pendidikan untuk mendorong pertumbuhan kesehatan individual, organisasi, dan masyarakat. Metode yang digunakan dalam program Diklat adalah :

1. Metode $O n$ the Job Site, dimana para peserta ditempatkan langsung pada area kerja/kondisi yang real. Metode yang dipakai adalah Pembekalan, Magang, Rotasi Jabatan dan Penugasan Sementara.

2. Metode Off the Job Site, dimana pelatihan dilaksanakan diluar tempat kerja. Metode yang diterapkan adalah Teknik Presentasi Informasi dan Teknik Simulasi.

Berdasarkan dari latar belakang masalah dan identifiakasi masalah, maka penulis tertarik untuk melakukan penelitian dengan judul :"Pelaksanaan Pendidikan dan Pelatihan Aparatur Sipil Negara Di Lingkungan Sekretariat Daerah Kota Pekanbaru Tahun 2016"

\section{METODE}

Jenis penelitian ini yaitu penelitian deskriptif dengan menggunakan pendekatan deskriptif kualitatif, bertujuan untuk memberikan gambaran tentang suatu gejala/suatu masyarakat tertentu. Penilitian kualitatif adalah suatu pendekatan yang mengungkap situasi sosial tertentu dengan mendeskripsikan kenyataan secara benar, dibentuk oleh kata-kata berdasarkan teknik pengumpulan dan analisis data yang relevan yang diperoleh dari situasi alamiah. Djam'an Satori dan Aan Komariah (2012:39). Penelitian ini penulis lakukan pada Kantor Sekretariat Daerah Kota Pekanbaru. Dengan alasan, ada indikasi atau fenomena tidak berjalannya secara maksimal pelaksanaan pendidikan dan pelatihan (diklat) pegawai Aparatur Sipil Negara (ASN) di lingkungan Sekretariat Daerah Kota Pekanbaru

\section{HASIL DAN PEMBAHASAN}

\subsection{Pelaksanaan Pendidikan dan Pelatihan (Diklat) Pegawai Aparatur Sipil Negara (ASN) di Lingkungan Sekretariat Daerah Kota Pekanbaru Tahun 2016}

Pendidikan dan pelatihan (diklat) adalah suatu proses yang akan menghasilkan suatu perubahan perilaku sasaran diklat yang mencakup aspek kognitif, afektif dan psikomotorik. Bila dilihat dari pendekatan sistem pendidikan dan pelatihan itu terdiri dari Input (sasaran diklat), output (perubahan perilaku), dan faktor yang mempengaruhi proses tersebut.

Soekidjo (2005: 31) menjelaskan bahwa pendidikan dan pelatihan adalah suatu proses yang akan menghasilkan suatu perubahan perilaku sasaran pendidikan dan pelatihan. Secara nyata perubahan perilaku berbentuk peningkatan mutu kemampuan dan keterampilan dari sasaran pendidikan dan pelatihan. Teori pendidikan dan pelatihan faktor yang mempengaruhi proses pendidikan dan pelatihan dibedakan menjadi dua yaitu perangkat lunak (software) dan perangkat keras(hardware).

Pendapat Soekidjo di atas sejalan dengan proses pendidikan dan pelatihan yang dikemukakan oleh Wursanto (2006: 89), bahwa hal-hal yang mempengaruhi diklat dibedakan mejadi dua, yaitu perangkat lunak (software) dan perangkat keras (hardware). Perangkat lunak dalam proses pendidikan dan pelatihan ini mencakup kurikulum, organisasi pendidikan dan pelatihan, peraturan-peraturan, metode belajar mengajar dan tenaga pengajar atau pelatih itu sendiri, sedangkan perangkat keras (hardware) yang juga besar pengaruhnya terhadap proses pendidikan dan pelatihan adalah fasilitas-fasilitas yang mencakup gedung, buku-buku referensi, alat bantu pendidikan, dan sebagainya.

Dasar hukum Diklat bagi Pegawai Negeri Sipil/Aparatur Sipil Negara adalah Peraturan Pemerintah Nomor 101 Tahun 2000 tentang Pendidikan dan Pelatihan Jabatan Pegawai Negeri Sipil. Berdasarkan Peraturan Pemerintah Nomor 101 tahun 2000 tentang Pendidikan dan Pelatihan Jabatan 
Pegawai Negeri Sipil, menekankan pada tujuan :

1. Meningkatkan pengetahuan, keahlian, keterampilan, dan sikap untuk dapat melaksanakan tugas jabatan secara profesional dengan dilandasi kepribadian dan etika Pegawai Negeri Sipil sesuai dengan kebutuhan instansi

2. Menciptakan aparatur yang mampu berperan sebagai pembaharu dan perekat persatuan dan kesatuan bangsa

3. Memantapkan sikap dan semangat pengabdian yang berorientasi pada pelayanan, pengayoman, dan pemberdayaan masyarakat

4. Menciptakan kesamaan visi dan dinamika pola pikir dalam melaksanakan tugas pemerintahan umum dan pembangunan demi terwujudnya kepemerintahan yang baik.

Sedangkan, sasaran Diklat bagi PNS/ASN adalah terwujudnya PNS/ASN yang memiliki kompetensi yang sesuai dengan persyaratan jabatan masing-masing serta fungsi Diklat meliputi dua fungsi sekaligus, yaitu fungsi pendidikan dan fungsi pelatihan yang merupakan satu kesatuan yang tidak terpisahkan. Diklat Prajabatan merupakan Diklat pembentukan awal bagi para Calon Pegawai Negeri Sipil diatur dalam Perka LAN No. 10, 15, dan 16 tahun 2015 dimana diklat ini ditujukan untuk membangun integritas moral, kejujuran, semangat dan motivasi.

Pengelolaan sumber daya manusia adalah suatu aspek yang dapat mendorong peningkatan kualitas pegawai. Mengingat pentingnya sumber daya manusia terhadap perkembangan dan kemajuan pemerintahan, pemerintah harus berupaya untuk meningkatkan kualitas sumber daya manusia yang dimiliki untuk mencapai tujuan pemerintahan tersebut. Salah satu cara yang dapat dilakukan untuk meningkatkan kualitas kinerja sumber daya manusia adalah melalui pelatihan sumber daya manusia. Mondy (2008: 210) menyebutkan bahwa pelatihan dan pengembangan merupakan jantung dari upaya berkelanjutan untuk meningkatkan kompetensi dan kualitas seseorang di dalam suatu organisasi. Pelatihan merupakan salah satu usaha untuk mengurangi atau menghilangkan kesenjangan antara kemampuan sumber daya manusia dengan kebutuhan yang dikehendaki. Dengan adanya kegiatan pelatihan maka diharapkan adanya peningkatan pengetahuan (knowledge), keahlian (skill), dan sikap (attitude) karyawan, sehingga tujuan dapat tercapai.

Dalam melakukan kegiatan pelatihan, terdapat dua metode yang dapat dilakukan yaitu metode on the job site dan off the job site. Pemilihan metode pelatihan sumber daya manusia yang tepat akan berdampak pada peningkatan kualitas pegawai. Pengertian on the job site menurut Swasto (2011:67) adalah suatu kegiatan pelatihan yang dilakukan ditempat kerja, dimana seorang mempelajari pekerjaan dengan melaksanakannya secara aktual dalam pekerjaan. Pada dasarnya setiap pegawai memperoleh pelatihan ditempat kerja ketika menjadi pegawai baru. Sedangkan pengertian off the job site menurut Simamora (2006: 320) adalah off the job site diselenggarakan dilokasi yang terpisah. Berdasarkan pengertian yang diungkapkan oleh para ahli diatas, maka perbedaan antara on the job site dan off the job site terdapat pada tempat penyelenggaraan dan materi yang diberikan. Metode pelatihan on the job site dilakukan ditempat kerja yang sesungguhnya dan dengan memberikan materi berupa tugas-tugas kepada pegawai untuk dikerjakan. Sedangakan metode pelatihan off the job site dilaksanakan diluar tempat kerja dan dengan memberikan materi-materi tertentu untuk diberikan kepada peserta pelatihan.

Sekretariat Daerah adalah unsur pembantu pimpinan pemerintah daerah, yang dipimpin oleh sekretaris daerah. Sekretaris daerah bertugas membantu kepala daerah dalam menyusun kebijakan dan mengkoordinasikan dinas daerah dan lembaga teknis daerah. Dalam pelaksanaan tugas dan kewajibannya, sekretaris daerah bertanggung jawab kepada Kepala Daerah. Sekretaris Daerah diangkat dari Pegawai Negeri Sipil (PNS) yang memenuhi persyaratan. Sekretaris Daerah karena kedudukannya sebagai pembina PNS di daerahnya. Sekretaris Daerah dapat disebut jabatan paling puncak dalam pola karier PNS di Daerah. Berikut jumlah pegawai di Sekretariat Daerah Kota Pekanbaru: 
Tabel 3.1

Jumlah Pegawai Sekretariat Daerah Kota Pekanbaru

\begin{tabular}{|c|l|r|}
\hline No & \multicolumn{1}{|c|}{ Nama Bagian } & Jumlah \\
\hline 1 & Bagian Umum & 55 \\
\hline 2 & Bagian Humas & 13 \\
\hline 3 & Bagian Keuangan \& Aset & 13 \\
\hline 4 & Bagian Protokol & 10 \\
\hline 5 & Bagian Kerja Sama & 8 \\
\hline 6 & Bagian Adm. Pembangunan dan PDE & 15 \\
\hline 7 & Bagian Adm. Perekonomian \& SDA & 10 \\
\hline 8 & Bagian Organisasi dan Tata Laksana & 10 \\
\hline 9 & Bagian Hukum & 8 \\
\hline 10 & Bagian Adm. Kesejahteraan Rakyat & 12 \\
\hline 11 & Pemerintahan Umum & 12 \\
\hline \multicolumn{2}{|c|}{ Jumlah } & $\mathbf{1 6 6}$ \\
\hline
\end{tabular}

Sumber : Sekretariat Daerah Kota Pekanbaru

Berdasarkan tabel di atas jumlah pegawai yang ada di Sekretariat Daerah Kota Pekanbaru berjumlah 166 orang, metode Diklat yang digunakan dalam pelaksanaan diklat di lingkungan Sekretariat Daerah Kota Pekanbaru adalah metode yang sesuai dengan tujuan dan program diklat bagi orang dewasa (andradogi). Diklat bagi orang dewasa (andradogi) adalah proses pendidikan membantu orang dewasa menemukan penemuan-penemuan dari bidang ilmu pengetahuan berhubungan dengan latar belakang sosial dan situasi pendidikan untuk mendorong pertumbuhan kesehatan individual, organisasi, dan masyarakat. Metode yang digunakan dalam program Diklat adalah :

1. Metode On the Job Site, dimana para peserta ditempatkan langsung pada area kerja/kondisi yang real. Metode yang dipakai adalah Pembekalan, Magang, Rotasi Jabatan dan Penugasan Sementara.

2. Metode Off the Job Site, dimana pelatihan dilaksanakan diluar tempat kerja. Metode yang diterapkan adalah Teknik Presentasi Informasi dan Teknik Simulasi.

Dalam prakteknnya, masing-masing metode pelatihan memiliki cara tersendiri untuk menyampaikan materi guna mencapai tujuan dan memberikan ilmu atau keahlian tambahan bagi pegawai. Masing-masing metode memiliki tujuan umum yang relatif sama yaitu guna mempersiapkan pegawai agar memiliki kemampuan yang dibutuhkan oleh pemerintahan, namun beberapa metode pelatihan juga memiliki tujuan khusus yang secara spesifik merupakan tujuan utama dari metode kegiatan pelatihan tersebut. Untuk lebih memaksimalkan hasil dari kegiatan pelatihan, tidak jarang menggabungkan beberapa metode pelatihan untuk memenuhi kemampuan pegawai yang dibutuhkan. Klasifikasi golongan pegawai yang mengikuti diklat prajabatan di lingkungan Sekretariat Daerah Kota Pekanbaru adalah sebagai berikut:

Tabel 3.2

Klasifikasi Golongan Pegawai yang mengikuti diklat di Lingkungan Sekretariat Daerah Kota Pekanbaru

\begin{tabular}{|l|l|r|}
\hline No & \multicolumn{1}{|c|}{ Klasifikasi Gololongan } & \multicolumn{1}{|c|}{ Jumlah } \\
\hline 1. & Golongan II A & 68 \\
\hline 2. & Golongan III A & 41 \\
\hline & Jumlah & $\mathbf{1 0 9}$ \\
\hline
\end{tabular}

Sumber : Sekretariat Daerah Kota Pekanbaru 2016 
Klasifikasi golongan pegawai yang mengikuti diklat prajabatan dari Golongan II A dan Golongan III A yang berjumlah 109 orang yang dilaksanakan oleh Badan Kepegawaian Daerah Kota Pekanbaru.Pelaksanaan pendidikan dan pelatihan merupakan suatu cara dengan metode yang sistematis yang dapat memberikan deskripsi secara luas serta dapat mengkondisikan penyelenggaraan pendidikan dan pelatihan untuk mengembangkan aspek kognitif, afektif dan psikomotorik tenaga kerja terhadap tugas dan pekerjaannya. Metode pendidikan dan pelatihan merupakan pendekatan terhadap cara penyelenggaraan dan pelaksanaan pendidikan dan pelatihan.

Penelitian ini bertujuan untuk mengetahui pelaksanaan pendidikan dan pelatihan (Diklat) pegawai Aparatur Sipil Negara (ASN) di Lingkungan Sekretariat Kota Pekanbaru. Dalam penelitian ini, terdapat dua macam metode yang digunakan dalam pelaksanaan pendidikan dan pelatihan pegawai, yaitu: Metode On The Job Site (latihan di dalam pekerjaan) dan Metode Off The Job Site (latihan di luar pekerjaan).

\subsubsection{Metode On The Job Site (Latihan di dalam Pekerjaan)}

Pendekatan on the job site adalah bentuk pelatihan ditempat kerja. Pada pendekatan ini pegawai belajar langsung di tempat kerjanya, menyesuikan metode kerja, melakukan adaptasi dengan pekerjaan, menggunakan media kerja atau alat kerja secara langsung dan belajar dari yang lain (Smith, 2000). Dalam pelaksanaan Diklat metode on the job site di lingkungan Sekretariat Daerah Kota Pekanbaru Pegawai Aparatur Sipil Negara (ASN) yang lebih berpengalaman dapat membantu pegawai yang lain dengan Menunjukkan kepada pegawai bagaimana melakukan pekerjaan tersebut. Hal tersebut disampaikan oleh Sekretaris Daerah Kota Pekanbaru mengenai Diklat Metode on the job site yang dilakukan di lingkungan Sekretariat Daerah Kota Pekanbaru.

"Pelatihan on the job site (latihan di dalam pekerjaan) yang dilakukan di Sekretariat Kota

Pekanbaru melibatkan semua pegawai, pegawai yang lebih berpengalaman dapat membantu pegawai yang lain dalam menjalankan pekerjaanya. Hal ini sangat membantu dalam menambah pengetahuan dan kreatifitas pegawai yang ada di lingkungan Sekretariat Daerah Kota Pekanbaru”. (Wawancara dengan Sekretaris Daerah Kota Pekanbaru Bapak Mohd Noer

Mbs di Kantor Walikota Pekanbaru 19 September 2017)

Menurut Cherrington (1995), mengatakan bahwa metode on the job site cenderung berfokus pada pengembangan dan pelatihan jangka panjang. Metode on the job site dibagi menjadi 6 macam yaitu:

1. Training instruksi pekerjaan (job instruction training)

Pelatihan ini memerlukan analisa kinerja pekerjaan secara teliti. Pelatihan ini dimulai dengan penjelasan awal tentang tujuan pekerjaan,dan menunjukan langkah-langkah pelaksanaan pekerjaan berdasarkan dari masing-masing tugas dasar pekerjaan.

2. Apprenticeship

Adalah suatu cara mengembangkan keterampilan pengrajin atau pertukangan. Pelatihan ini mengarah pada proses penerimaan karyawan baru, yang bekerja sama dan dibawah bimbingan praktisi yang ahli untuk beberapa waktu tertentu. Keefektifan pelatihan ini tergantung pada kemampuan praktisi yang ahli dalam mengawasi proses pelatihan. Pelatihan ini tidak mempunyai standar format.

3. Internship dan Assistantships

Pelatihan ini hampir sama dengan pelatihan apprenticeship tetapi mengarah pada kekosongan pekerjaan yang menuntut pendidikan formal yang lebih tinggi. Contoh internship training adalah magang.

4. Job rotation dan transfer

Pelatihan ini adalah proses belajar yang biasanya untuk mengisi kekosongan dalam manajemen dan teknikal. Pelatihan ini terdapat 2 kerugian yaitu peserta pelatihan hanya merasa dipekerjakan sementara dan tidak mempunyai komitmen untuk terlibat dalam pekerjaan dengan sungguhsungguh, dan banyak waktu yang terbuang untuk memberi orientasi pada perserta terhadap 
kondisi pekerjaan yang baru. Tetapi pelatihan ini juga mempunyai keuntungan yaitu jika pelatihan ini diberikan oleh manajer yang ahli maka peserta akan memperoleh tambahan pengetahuan mengenai pelaksanaan dan praktek dalam pekerjaan.

5. Junior boards dan Committee assingments

Pelatihan dengan memindahkan perserta pelatihan ke dalam komite untuk bertanggungjawab dalam pengambilan keputusan administrasi. Dan juga menempatkan perserta dalam anggota eksekutif agar memperoleh kesempatan dalam berinteraksi dengan eksekutif yang lain.

6. Couching dan Counseling

Pendekatan ini menurut Sule dan Saefullah (2009:205)dalam bentuk coaching dan counseling yaitu bimbingan yang diberikan fasilitator atau atasan kepada bawahan yang bertindak sebagai coach mengenai berbagai hal yang terkait dengan pekerjaan. Pembimbingan adalah kombinasi observasi dengan pemberian arahan. Seperti modeling, ini merupakan cara yang paling alamiah untuk belajar. Dalam konteks prilaku, pembimbingan dapat dicapai dengan lebih baik jika melibatkan hubungan yang sehat antara pegawai dengan fasilitator/coach selama peiode waktu mereka mengerjakan pekerjaan mereka. Secara sederhana menurut (Smith, 169:2000) metode pelatihan ini dapat dilakukan oleh fasilitator sebagai berikut:

1. Menunjukkan kepada pegawai bagaimana melakukan pekerjaan tersebut.

2. Menunjukkan poin-poin penting dari pekerjaan tersebut.

3. Memberi kesempatan mereka untuk melihat bagaimana melakukannya.

4. Memberi kesempatan mereka mengerjakan bagian-bagian pekerjaan yang sederhana.

5. Membantu menyelesaikan seluruh pekerjaan.

6. Membiarkan mereka melakukan pekerjaan tersebut, dalam pengawasan fasilitator.

7. Membiarkan pegawai tersebut melakukan pekerjaan tersebut secara mandiri.

On the job site merupakan pelatihan yang dilakukan ditempat kerja, dimana seorang mempelajari pekerjaan dengan melaksanakannya secara aktual dalam pekerjaan dan pada dasarnya setiap pegawai memperoleh pelatihan ditempat kerja.Pelatihan ini berbentuk penugasan pegawai-pegawai baru pada pegawai yang telah berpengalaman (senior). Hal ini berarti pegawai baru, meminta kepada para pegawai yang sudah berpengalaman untuk membimbing atau mengajarkan pekerjaan yang baik kepada para pegawai baru.

Metode on-the-jobsite merupakan metode latihan yang paling banyak digunakan. Latihan dengan menggunakan metode ini dilakukan di tempat kerja. Pegawai dilatih tentang pekerjaan baru dengan supervisi langsung seorang pelatih yang berpengalaman (biasanya pegawai lain). Metode latihan ini dirasa lebih ekonomis karena pegawai langsung dilibatkan pada pekerjaan, bukan hanya simulasi sehingga tidak memerlukan waktu khusus.

On the job site merupakan metode pelatihan yang paling banyak digunakan. Pelatihan dengan cara seperti ini adalah dimana para pegawai ditempatkan dalam kondisi pekerjaan yang real dibawah bimbingan dan supervise dari pegawai yang berpengalaman atau seorang supervisor. Dalam prakteknya on the job site memiliki beberapa metode yang sering digunakan metode-metode yang biasa digunakan dalam praktik adalah sebagai berikut:

\subsubsection{Pembekalan (Coaching)}

Pelatihan ini dilakukan di tempat kerja oleh atasan dengan cara memberikan bimbingan dan pengarahan kepada pegawai bagaimana melaksanakan pekerjaan rutin mereka. Coaching biasanya ditangani oleh pegawai yang pangkatnya lebih tinggi atau yang lebih berpengalaman.

Pembekalan adalah suatu cara pelaksanaan pelatihan dimana atasan mengajarkan keahlian dan keterampilan kerja kepada bawahannya. Dalam metode ini pengawas diperlukan sebagai petunjuk untuk memberitahukan kepada peserta mengenai tugas atau pekerjaan rutin yang akan dilaksanakan dan 
bagaimana cara mengerjakannya.Dilaksanakan dengan cara peserta harus mengerjakan tugas dengan dibimbing oleh pejabat senior atau ahli.

Pelaksanaan pelatihan pembekalan (coaching) yang dilakukan di Sekretariat Daerah Kota Pekanbaru seperti contoh Kepala Bagian Administrasi Pemerintahan Umum mendengarkan dan menentukan apakah yang dikerjakan pegawai yang di bawahnya sudah benar atau masih salah dalam menjalankan tugas Bagian Administrasi Pemerintahan Umum yang mempunyai tugas pokok melaksanakan sebagian tugas Sekretariat Daerah dalam mengkoordinasikan seluruh proses pengawasan, tugas pembantuan, ketenteraman dan ketertiban, perlindungan masyarakat, penanggulangan bencana, kependudukan, agraria dan kerjasama dan penanganan perbatasan. Atasan memberikan umpan balik dan memperlihatkan bagaimana sebaiknya hal tersebut dicapai atau dilakukan, selanjutnya pegawai mengevaluasi situasi dan perilakunya. Pelaksanaan pelatihan dengan cara pembekalan ini Kepala Bagian Administrasi Pemerintahan Umum mengatakan:

"Pembekalan (Coaching) ini biasanya kita lakukan setiap hari senin setelah apel pagi, semua pegawai saya berikan arahan dalam menjalankan tugasnya jika ada terjadi permasalahan maka akan dicari solusinya" (Wawancara dengan Kepala Bagian Administrasi Pemerintahan Umum Bapak Azwan di Kantor Walikota Pekanbaru 14 September 2017)

Berdasarkan wawancara di atas bahwa pelatihan pembekalan (Coaching) biasanya dilakukan setiap hari senin yaitu setelah apel pagi, tidak adanya waktu atasan untuk melakukan pelatihan pembekalan ini, mengakibatkan pegawai kurang terampil dalam menjalankan tugasnya.

Penyuluhan efektif bila latihannya diindividualisasikan dan peserta belajar melakukan pekerjaan langsung. dengan memberikan petunjuk-petunjuk pekerjaan secara langsung pada pekerjaan dan terutama digunakan untuk melatih para pegawai tentang cara-cara pelaksanaan pekerjaan sekarang. Pada metode ini didaftarkan semua langkah-langkah yang perlu dilakukan dalam pekerjaan sesuai dengan urutannya.

Salah satu teknik dalam on the job dimana pelatih (trainer) diberikan pelatihan terlebih dahulu sebelum trainer tersebut itu memberikan pelatihan kepada staff. Kelebihan dari metode ini adalah pelatih telah mendapatkan keahlian tentang cara melatih sehingga pelatihan dapat dilakukan dengan lebih maksimal dan memudahkan transfer belajar kepada para peserta/pegawai juga dapat menciptakan hubungan langsung antara pegawai dengan pelatih. Sedangkan kelemahannya adalah tidak memberikan waktu kerja penuh yang sesungguhnya.

\subsubsection{Rotasi Jabatan}

Rotasi jabatan Merupakan perpindahan posisi pegawai dari satu pekerjaan ke pekerjaan lainnya. Beberapa keuntungan dari metode rotasi jabatan adalah pegawai akan mendapatkan gambaran yang luas mengenai berbagai macam jenis pekerjaan dalam melakukan pekerjaannya, mengembangkan kerja sama antar pegawai, menentukan jenis pekerjaan yang sangat diminati oleh pegawai, mempermudah menyesuaikan diri dengan lingkungan tempat bekerja, dan sebagai bahan pertimbangan dalam menentukan penempatan kerja yang sesuai dengan potensi pegawai tersebut. Rotasi jabatan ini merupakan metode yang paling sering digunakan.

Rotasi jabatan ini direncanakan secara formal dengan cara menugaskan pegawai pada beberapa pekerjaan yang berbeda dan bagian yang berbeda untuk menambah pengetahuan mengenai pekerjaan. Rotasi jabatan ini dilakukan di lingkungan Sekretariat Daerah Kota Pekanbaru secara luas sebagai teknik pengembangan. Pelaksanaan rotasi jabatan ini diharapkan mampu menambah keterampilan pegawai yang ada di lingkungan Sekretariat Daerah Kota Pekanbaru dengan cara melakukan pekerjaan yang berbeda, pelaksanaan rotasi jabatan dilakukan dengan cara pegawai yang bekerja di bagian administrasi pemerintahan umum diberi pelatihan mengenai bagian administrasi kesejahteraan rakyat untuk menantisipasi suatu saat kekurangan pegawai di bagian administrasi kesejahteraan rakyat.

"Untuk pengembangan pengetahuan pegawai dan kerjasama antar pegawai perlu diadakan rotasi jabatan ini untuk mewujudkan hal tersebut, walaupun jabatan yang 
dilakukanya bersifat sementara dan tidak tetap" (Wawancara dengan Kepala Badan Kepegawaian Daerah Kota Pekanbaru Bapak Ikhwan Ridwan SH, M.Si di Kantor Walikota Pekanbaru 14 September 2017)

Berdasarkan wawancara dengan Kepala Badan Kepegawaian Daerah Kota Pekanbaru yang mengatakan bahwa perlu diadakan rotasi jabatan ini untuk pengembangan pengetahuan dan kerja sama pegawai yang ada di lingkungan Sekretariat Daerah Kota Pekanbaru, walaupun jabatannya hanya sementara dan tidak tetap. Berikut ini jumlah pegawai di lingkungan Sekretariat Daerah Kota Pekanbaru yang mengikuti Rotasi Jabatan dari tahun 2013-2014 :

\section{Table 3.3}

Jumlah Aparatur Sipil Negara yang mengikuti Rotasi Jabatan dari Tahun $2013-2014$

\begin{tabular}{|l|c|c|}
\hline No & Tahun & Jumlah \\
\hline 1 & 2013 & $\mathbf{2 4}$ \\
\hline 2 & 2014 & $\mathbf{4 2}$ \\
\hline 3 & 2015 & $\mathbf{3 8}$ \\
\hline 4 & 2016 & $\mathbf{5 4}$ \\
\hline
\end{tabular}

Sumber : Data Olahan 2017

Melihat pelaksanaan rotasi jabatan yang dilakukan di Sekretariat Daerah Kota Pekanbaru setiap tahunnya diikuti 24 - 54 pegawai, rotasi jabatan ini dilaksanakan atas perintah dari atasan langsung untuk pengembangan pengetahuan dan kerjasama pegawai, kendalanya tidak adanya tanggung jawab terhadap pegawai yang di rotasi, hal ini mengakibatkan kurang maksimalnya kinerja yang dilakukan pegawai tersebut karena tidak adanya tanggung jawab atas pekerjaanya.

Tujuan rotasi jabatan adalah memperluas latar belakang pegawai. Pegawai berpindah dalam periode tertentu dan diberi pengetahuan tentang bagian-bagian organisasi yang berbeda serta praktek berbagai macam keterampilan.Keuntungan menggunakan metode ini dalam pelaksanaan diklat di lingkungan Sekretariat Daerah Kota Pekanbaru antara lain :

1. Memberi latar belakang umum tentang organisasi, dan memberi sudut pandang bersifat organisasional.

2. Mendorong kerja sama antar organisasi.

3. Memperkenalkan sudut pandang yang segar secara periodik kepada berbagai unit.

4. Mendorong keluwesan organisasi melalui penciptaan sumber daya manusia yang fleksibel.

5. Mampu melaksanakan penilaian presentasi secara komparatif dengan lebih obyektif.

6. Memperoleh keunggulan dalam setiap situasi.

Sedangkan kelemahan metode ini dalam pelaksanaan diklat di lingkungan Sekretariat Daerah Kota Pekanbaru adalah:

1. Tidak memberikan tanggung jawab penuh terhadap pegawai yang sedang dirotasi.

2. Waktu kerja singkat.

\subsubsection{Magang (Apprenticeship training)}

Pelatihan ini mengkombinasikan antara pelajaran di kelas dengan praktik di lapangan. Peserta pelatihan magang bekerja dan berlatih di bawah pengawasan langsung ahli tersebut. Biasanya metode ini digunakan untuk jenis pekerjaan yang memerlukan skill tinggi.

Pelatihan magang ini merupakan proses belajar dari seseorang atau beberapa orang yang lebih berpengalaman. Metode ini digunakan untuk mengembangkan keahlian perorangan, sehingga para pegawai yang bersangkutan dapat mempelajari segala aspek dari pekerjaannya.

Magang dilakukan di lingkungan Sekretariat Daerah Kota Pekanbaru dengan cara pegawai yang berasal dari luar kota atau sebelumnya bekerja di luar lingkungan Sekretariat Daerah Kota Pekanbaru 
maka pegawai tersebut akan mengikuti magang untuk mempelajari bagaimana cara melakukan sesuatu kegiatan. Metode ini digunakan untuk mengembangkan keahlian perorangan sehingga para pegawai dapat mempelajari segala aspek dari pekerjaannya. Berikut wawancara dengan Kepala Badan Kepegawaian Daerah Kota Pekanbaru mengenai pelaksanaan magang di lingkungan Sekretariat Daerah Kota Pekanbaru:

"Sebagai contoh dalam pelaksanaan magang di Sekretariat Daerah Kota Pekanbaru pegawai aparatur sipil negara yang berasal dari luar kota perlu penyesuaian terhadap lingkunganya maka akan dilakukan magang terhadap pegawai tersebut" (Wawancara dengan Kepala Badan Kepegawaian Daerah Kota Pekanbaru Bapak Ikhwan Ridwan SH, M.Si di Kantor Walikota Pekanbaru 14 September 2017)

Kelebihan pelaksanaan magang di lingkungan Sekretariat Daerah Kota Pekanbaru adalah pegawai tidak turut campur secara langsung dalam pekerjaan sehingga tidak mempengaruhi pekerjaan pemangku jabatan tertentu. Selain itu magang juga dapat memberikan pelatihan yang ekstensif. Sedangkan kelemahan magang adalah waktunya yang relatif lama, biaya yang cukup mahal, dan kemungkinan kurangnya motivasi dari pemangku jabatan tertentu sehingga tidak menunjukkan pekerjaan yang benar.

\subsubsection{Penugasan Sementara}

Penugasan sementara merupakan penempatan pegawai pada posisi tertentu untuk memberikan pengalaman kepada pegawai yang mendapat tugas sementara untuk menangani masalah-masalah khusus secara aktual (Swasto, 2011:67). Dengan adanya penugasan sementara, pegawai diharapkan mampu mengembangkan potensi yang dimilikinya untuk mendapatkan pengalaman dan pengetahuan baru.

Pelaksanaan kegiatan penugasan sementara di lingkungan Sekretariat Daerah Kota Pekanbaru pegawai ditugaskan pada suatu posisi untuk jangka waktu tertentu, misalnya 3 (tiga) bulan. Disini, pegawai terlibat dalam pengambilan keputusan untuk masalah yang mereka hadapi. Penempatan peserta/pegawai pada posisi penugasannya untuk jangka waktu yang ditetapkan. Pegawai terlibat dalam pengambilan keputusan dan pemecahan masalah-masalah. Berikut wawancara dengan Kepala Badan Kepegawaian Daerah Pekanbaru tentang pelatihan penugasan sementara yang dilakukan di lingkungan Sekretariat Daerah Kota Pekanbaru:

"Dengan adanya penugasan sementara dapat mengembangkan potensi pegawai untuk mendapatkan pengalaman dan pengetahuan baru dan pegawai sudah diberikan tanggung jawab langsung atas penugasannya sehingga ia bisa bekerja dengan serius." (Wawancara dengan Kepala Badan Kepegawaian Daerah Kota Pekanbaru Bapak Ikhwan Ridwan SH, M.Si di Kantor Walikota Pekanbaru 14 September 2017)

Kelebihan penugasan sementara dalam pelatihan di lingkungan Sekretariat Dareah Kota Pekanbaru adalah peserta/pegawai diberikan tanggung jawab secara langsung sehingga peserta/pegawai bekerja dengan serius. Kelemahnnya adalah tentang pemberian waktu yang relatif singkat.

On the Job Site memiliki beberapa keunggulan. Metode ini relatif tidak mahal karena orang yang dilatih belajar sambil bekerja. Tidak membutuhkan fasilitas diluar kantor yang mahal seperti ruang kelas atau peralat belajar tertentu. Metode ini juga memberikan pembelajaran, karena orang yang dilatih belajar sambil melakukannya dan mendapatkan timbal balik yang cepat atasprestasi mereka. Tetapi ada beberapa hal untuk diperhatikan saat menggunakan On The Job Site.

Paling penting, jangan terlalu mengandalkan keberhasilan dari sebuah program On the Job Site. Latihlah para pelatih dengan hati-hati, dan berikan bahan pelatihan yang diperlukan. Misalnya, para pelatih harus mengetahui prinsip-prinsip belajar dan empat-langkah teknik instruksi. Harapan yang rendah dan peran pelatih bisa menghasilkan prestasi yang buruk dari orang yang dilatih Jadi orang yang melatih harus menekankan harapan yang tinggi untuk keberhasilan orang-orang yang mereka latih.

Berdasarkan penjelasan di atas Penyelenggaraan on the job site yang dilaksanakan di lingkungan Sekretariat Daerah Kota Pekanbaru mempunyai keuntungan dan kelemahan yang perlu mendapatkan 
perhatian dari pemerintah. Keuntungan metode on the job site dalam pelaksanaan diklat pegawai Aparatur Sipil Negaradi lingkungan Sekretariat Daerah Kota Pekanbaru adalah:

1. Biaya dapat ditekan serendah mungkin, karena tidak perlu mengeluarkan biaya sewa tempat dan peralatan yang digunakan.

2. Tidak diperlukan masa penyesuaian atau pengenalan terhadap atasan maupun bawahan dalam melaksanakan Pendidikan dan Pelatihan ini.

3. Telah terjalin komunikasi yang baik antar atasan atau pegawai yang berpengalaman dengan pegawai baru sehingga dapat dijamin adanya kelancaran program pelatihan.

Sedangkan Kelemahan metode on the job site dalam pelaksanaan diklat pegawai Aparatur Sipil Negaradi lingkungan Sekretariat Daerah Kota Pekanbaruadalah :

1. Tidak mudah memperoleh pegawai yang berpengalaman dari dalam karena adanya keterbatasan kemampuan atau waktu.

2. Jumlah peserta harus memenuhi rasio yang menguntungkan.

3. Sulitnya mengatur waktu belajar, artinya banyak hal-hal yang harus dipertimbangkan.

Tenaga Kediklatan adalah mereka yang ditugaskan oleh Pejabat Pembina Kepegawaian Instansi/Pimpinan Lembaga Diklat Terakreditasi, yang terdiri dari terdiri dari:

1) Widyaiswara

Widyaiswara adalah PNS yang diangkat sebagai pejabat fungsional oleh pejabat yang berwenang dengan tugas, tanggung jawab, wewenang untuk mendidik, mengajar, dan atau melatih pada Lembaga Diklat Pemerintah.

2) Pengelola dan Penyelenggara Diklat Pemerintah

Pengelola Lembaga Diklat Pemerintah adalah PNS yang bertugas pada lembaga Diklat instansi pemerintah yang secara fungsional.

2) Tenaga Kediklatan lainnya adalah pejabat atau seseorang yang bukan Widaiswara, bukan pengelola lembaga diklat pemerintah tetapi karena kemampuan atau kedudukannya diikutsertakan dalam kegiatan pencapaian tujuan diklat.

Pembimbingan yang efektif menuntut adanya kesabaran dan keterampilan komunikasi yang baik. Uraian singkat dari petunjuk akan suatu pembimbinganyang baik antara lain mencakup :

1. Penjelasan akan perilaku yang pantas

2. Menjelaskan mengapa tindakan - tindakan tertentu harus diambil

3. Secara akurat menetapkan pengamatan - pengamatan

4. Memberikan sara/alternatif yang memungkinkan

5. Menindak lanjuti/mendorong

Mathis dan Jackson (2002:60) mengemukakan bentuk bimbingan dapat berupa hubungan di mana para pegawai pada titik tengah karier mereka yang menjadi pembimbing/coachindividu-individu yang berada di awal karier mereka. Keuntungan dari pendekatan ini adalah adanya transfer ilmu antar individu dalam organisasi, dan terjadinya pengembangan kompetensi.

Pelatihan ini berbentuk penugasan pegawai-pegawai baru pada pegawai yang telah berpengalaman (senior). Hal ini berarti pegawai baru, meminta kepada para pegawai yang sudah berpengalaman untuk membimbing atau mengajarkan pekerjaan yang baik kepada para pegawai baru.

Menurut Handoko (2010: 112), Metode on-the-jobsite merupakan metode latihan yang paling banyak digunakan. Latihan dengan menggunakan metode ini dilakukan di tempat kerja. Pegawai dilatih tentang pekerjaan baru dengan supervisi langsung seorang pelatih yang berpengalaman (biasanya pegawai lain). Metode latihan ini dirasa lebih ekonomis karena pegawai langsung dilibatkan pada pekerjaan, bukan hanya simulasi sehingga tidak memerlukan waktu khusus. 


\subsubsection{Metode Off The Job Site (latihan di luar pekerjaan)}

Pada umumnya pendekatan pelatihan di luar pekerjaan dilakukan di tempat-tempat pemusatan pelatihan pegawai seperti Badan Kepegawaian Daerah atau pusat pengembangan pegawai. Sule dan Saefullah (2009:205) secara garis besar mengemukakan program pengembangan pegawai dalam organisasi yaitu off the job site antaranya yaitu,

1. Executive development programme, yaitu program pengiriman pegawai untuk berpartisipasi dalam berbagai program khusus di luar organisasi yang terkait dengan analisis kasus, simulasi, maupun metode pembelajaran lainnya.

2. Laboratoty training, yaitu berupa program yang ditujukan kepada pegawai untk mengikuti program - program simulasi atas dunia nyata yang terkait dengan kegiatan organisasi dimana metode yang biasa digunakan adalah metode role playing, simulasi dan lain-lain.

3. Organisational development, yaitu program yang ditujukan kepada pegawai dengan mengajak mereka untuk berfikir mengenai bagaimana cara memajukan organisasi

Pengembangan pegawai diluar pekerjaan yang dilakukan Sekretariat Daerah Kota Pekanbaru dalam bentuk pelatihan yang dilaksanakan oleh Badan Kepegawaian Daerah Kota Pekanbaru. Pelatihan (training) adalah proses sistematik pengubahan perilaku para pegawai dalam suatu arah guna meningkatkan tujuan-tujuan organisasi atau mempelajari sikap, kemampuan, keahlian, pengetahuan, dan perilaku yang spesifik yang berkaitan dengan pekerjaan. Dalam pelaksanaan pengembangan pegawai di luar tempat kerja Sekretaris Daerah Kota Pekanbaru mengatakan:

"Pada tahap pelaksanaan pelatihan di luar pekerjaan dilakukan dengan cara memakai teknik simulasi dan teknik presentasi informasi metode ini dapat meningkatkan pengetahuan dan kemampuan pegawai untuk lebih berkonsentrasi terhadap apa yang harus dipelajari."

(Wawancara dengan Sekretaris Daerah Kota Pekanbaru Bapak Mohd Noer Mbs di Kantor Walikota Pekanbaru 19 September 2017)

Menurut Cherrington (1995) sebagaimana dikemukakan Sujoko (2012), metode Off the job site dibagi menjadi 13 macam, antara lain:

\section{Vestibule training}

Pelatihan dimana dilakukan ditempat tersendiri yang dikondisikan seperti tempat aslinya. Pelatihan ini digunakan untuk mengajarkan keahlian kerja yang khusus.

\section{Lecture}

Merupakan pelatihan dimana menyampaikan berbagai macam informasi kepada sejumlah besar orang pada waktu bersamaan.

3. Independent self-study

Pelatihan yang mengharapkan peserta untuk melatih diri sendiri misalnya dengan membaca buku, majalah profesional, mengambil kursus pada universitas lokal dan mengikuti pertemuan profesional.

4. Visual presentations

Pelatihan dengan mengunakan televisi, film, video, atau persentasi dengan menggunakan slide.

5. Conferencesdan Discusion

Pelatihan ini biasa digunakan untuk pelatihan pengambilan keputusan dimana peserta dapat belajar satu dengan yang Iainnya.

6. Teleconferencing

Pelatihan dengan menggunakan satelit, dimana pelatih dan peserta dimungkinkan untuk berada di tempat yang berbeda.

7. Case studies

Pelatihan yang digunakan dalam kelas bisnis, dimana peserta dituntut untuk menemukan prinsip-prinsip dasar dengan menganalisa masalah yang ada. 
8. Role play

Pelatihan dimana peserta dikondisikan pada suatu permasalahan tertentu, peserta harus dapat menyelesaikan permasalahan dimana peserta seolah-olah terlibat langsung.

\section{Simulation}

Pelatihan yang menciptakan kondisi belajar yang sangat sesuai atau mirip dengan kondisi pekerjaan, pelatihan ini digunakan untuk belajar secara teknikal dan motor skill.

10. Programmed instruction

Merupakan aplikasi prinsip dalam kondisi operasional, biasanya menggunakan komputer.

11. Computer-based training

Merupakan program pelatihan yang diharapkan mempunyai hubungan interaktif antara komputer dan peserta, dimana peserta diminta untuk merespon secara langsung selama proses belajar.

12. Laboratory training

Pelatihan ini terdiri dari kelompok-kelompok diskusi yang tidak beraturan dimana peserta diminta untuk mengungkapkan perasaan mereka terhadap satu dengan yang lain. Tujuan pelatihan ini adalah menciptakan kewaspadaan dan meningkatkan sensitivitas terhadap perilaku dan perasaan orang lain maupun dalam kelompok.

13. Programmed group excercise

Pelatihan yang melibatkan peserta untuk bekena sama dalam memecahkan suatu permasalahan.

Pendidikan dan pelatihan dengan menggunakan metode ini karena memberikan kesempatan kepada individu untuk lebih berkonsentrasi terhadap apa yang harus dipelajari. Selain itu, pertemuan dengan peserta yang lain membuat mereka mendapatkan wawasan baru. Metode ini mempunyai dua macam teknik, yaitu :

\subsubsection{Teknik Presentasi Informasi}

Salah satu Diklat diluar pekerjaan yang dilakukan oleh Sekretariat Daerah Kota Pekanbaru dengan menggunakan Teknik Presentasi Informasi untuk menyajikan informasi yang tujuannya mengintroduksikan pengetahuan, sikap, dan keterampilan baru kepada para pegawai. Harapan akhir dari proses pengetahuan, sikap, dan keterampilan pegawai diadopsi oleh pegawai pendidikan dan pelatihan di dalam pekerjaannya nanti. Teknik ini terdiri dari:

1. Ceramah biasa, dimana pengajar (pelatih) bertatap muka langsung dengan peserta. Peserta pendidikan dan pelatihan pasif mendengarkan.

2. Teknik diskusi, dimana informasi yang akan disajikan disusun di dalam bentuk pertanyaanpertanyaan atau tugas-tugas yang harus dibahas dan didiskusikan oleh para peserta aktif.

3. Diskusi kelompok adalah suatu proses interaksi secara lisan mengenai tujuan tertentu yang di dalamnya melibatkan beberapa peserta dengan cara tatap muka, melalui tukar-menukar informasi atau pemecahan suatu masalah/persoalan.

5. Teknik pemodelan perilaku adalah salah satu cara mempelajari atau meniru tindakan (perilaku) dengan mengobservasi dan meniru model-model. Biasanya model-model perilaku yang harus diobservasi dan ditiru diproyeksikan dalam video tape.

6. Teknik magang ialah pengiriman pegawai dari suatu organisasi ke badan-badan atau organisasi yang lain yang dianggap lebih maju baik secara kelompok maupun perorangan. Mereka mempelajari teori-teori dan langsung mempraktikkan di bawah pengawasan, hal-hal baru, keterampilan baru yang harus mereka terapkan di dalam organisasi tersebut.

\subsubsection{Teknik Simulasi}

Berikutnya diklat diluar pekerjaan yang dilakukan oleh Sekretariat Daerah Kota Pekanbaru dengan menggunakan teknik Simulasi yaitu suatu penentuan karakteristik atau perilaku tertentu dari dunia 
nyata sedemikian rupa sehingga, para peserta dapat merealisasikan seperti keadaan sebenarnya. Dengan demikian, maka apabila pesertapendidikan dan pelatihan kembali ke tempat pekerjaan semula akan mampu melakukan pekerjaan yangdisimulasikan tersebut. Metode-metode simulasi yang dilakukan di Sekretariat Daerah Kota Pekanbaru adalah sebagai berikut:

1. Simulator alat-alat, misalnya simulasi alat-alat kantor bagi kearsipan di Sekretariat Daerah Kota Pekanbaru.

2. Studi kasus (case study), di mana para peserta pendidikan dan pelatihan diberikan suatu kasus, kemudian dipelajari dan didiskusikan oleh peserta pendidikan dan pelatihan. Kasus atau masalah yang diberikan merupakan situasi yang membutuhkan keputusan dan tindakan yang sesuai. Oleh karena itu, studi kasus harus bisa membuat pikiran para peserta pendidikan dan pelatihan terpusat pada kondisi khusus yang sama dengan kondisi yang mungkin mereka alami.

3. Permainan peranan (role playing). Cara ini mengajak peserta untuk memainkan peran, bagianbagian dari karakter (watak) dalam kasus. Para peserta diminta untuk membayangkan diri sendiri tentang tindakan (peranan) tertentu yang diciptakan bagi mereka oleh pelatih. Metode permainan peran (role playing) dapat diartikan sebagai suatu metode pendidikan dan pelatihan dimana terlibat proses interaksi hubungan individu baik sebenarnya maupun tiruan yang diperankan secara spontan.

4. Teknik di dalam keranjang (in basket). Metode ini dilakukan dengan memberikan bermacammacam persoalan kepada para peserta. Dengan kata lain, peserta diberi suatu basket atau keranjang yang penuh dengan bermacam-macam persoalan yang diatasi

Seperti halnya penyelenggaraan on the job site di lingkungan Sekretariat Daerah Kota Pekanbaru, penyelenggaraan off the job site di lingkungan Sekretariat Daerah Kota Pekanbarujuga ada kelebihan dan kelemahan. Kelebihan pelaksanaan pendidikan dan pelatihan off the job site pada pegawai aparatur sipil negara (ASN) di lingkungan Sekretariat Daerah Kota Pekanbarua dalah:

1. Tidak perlu dalam jumlah yang banyak (memenuhi rasio) karena sifatnya penitipan.

2. Organisasi tidak disibukkan dengan pekerjaan tambahan dalam penyelenggaraan latihan tersebut.

3. Pegawaai dapat memusatkan perhatian karena dapat melepaskan diri dari pekerjaan rutin.

4. Pegawai mempunyai pengetahuan yang relatif lebih luas,karena tidak terpaku pada lingkungan kerjanya seharihari dan dari segi lain dapat memperluas pergaulan yang sangat bermanfaat dalam hubungan pekerjaan baik jangka pendek maupun jangka panjang.

Adapun kelemahan pelaksanaan pendidikan dan pelatihan off the job site pada pegawai aparatur sipil negara (ASN) di lingkungan Sekretariat Daerah Kota Pekanbaru adalah:

1. Peserta adakalanya tidak dapat langsung menerapkan pengetahuan atau keterampilan yang diperoleh dari latihan.

2. Biaya yang dikeluarkan relatif lebih besar dari biaya apabila latihan itu diselenggarakan sendiri oleh organisasi atau instansi.

Disamping teknik-teknik atau metode-metode pelatihan yang telah diuaraikan diatas, pemilihan dan penggabungan beberapa metode pelatihan yang dilakukan dengan tepat dapat memberikan kesesuaian dengan kondisi yang dihadapi oleh peserta untuk menyelesaikan masalah-masalah yang mungkin timbul dalam pekerjaannya. Pemilihan metode-metode pelatihan yang sesuai dengan kebutuhan dan kondisidapat memberikan efektivitas pelaksanaan pelatihan untuk mencapai tujuan.

\subsection{Hambatan dalamPelaksanaan Pendidikan dan Pelatihan (Diklat) Pegawai Aparatur Sipil Negara (ASN) di Lingkungan Sekretariat Daerah Kota Pekanbaru Tahun 2016}

Hambatan pelaksanaan pelatihan adalah suatu bentuk halangan atau kendala dalam memutuskan proses pelaksanaan pelatihan. Hambatan ini dapat berasal dari dalam organisasi ataupun lingkungan luar 
organisasi. Hambatan didalam pelaksanaan program pelatihan biasanya merupakan faktor penghalang bagi organisasi dalam melaksanakan rancangan program pelatihan. Dilihat dari segi pentingnya pelatihan, hal ini sangat tidak diinginkan oleh semua pihak yang terlibat didalam pelaksanaan pelatihan.

Adapun faktor-faktor yang menjadi kendala dalam pelaksanaan pendidikan dan pelatihan (Diklat) Pegawai Aparatur Sipil Negara di Lingkungan Sekretariat Daerah Kota Pekanbaru yaitu:

1. Tidak mudah memperoleh pegawai yang berpengalaman dari dalam karena adanya keterbatasan kemampuan atau waktu.

2. Jumlah peserta harus memenuhi rasio yang menguntungkan.

3. Sulitnya mengatur waktu belajar, artinya banyak hal-hal yang harus dipertimbangkan.

4. Pegawai yang berpengalaman (senior) kurang memberikan semangat atau dorongan kepada pegawai baru, sehingga saat pembelajaran dimulai suasana tidak kondusif dan para pegawai cenderung tidak bergairah untuk mengikuti Diklat.

5. Peserta adakalanya tidak dapat langsung menerapkan pengetahuan atau keterampilan yang diperoleh dari latihan.

6. Biaya yang dikeluarkan relatif lebih besar dari biaya apabila latihan itu diselenggarakan sendiri oleh instansi.

Berdasarkan penjelasan tersebut di atas, penulis melihat bahwa pelaksanaan pendidikan dan pelatihan (diklat) diselenggarakan di lingkungan Sekretariat Dareah Kota Pekanbaru tidak berjalan secara maksimal karena masih terdapat hambatan dalam pelaksanaanya. Dengan begitu, diharapkan setelah diadakannya Diklat dapat menunjukkan SDM Aparatur kearah yang lebih baik. seperti seperti pelayanan yang lebih mudah kepada masyarakat, PNS lebih disiplin dan taat pada peraturan organisasi, tidak adanya PNS yang berkeliaran pada saat jam kerja, serta semakin kreatif dan inovatif. Harapan lainnya yaitu para alumni/peserta Diklat dapat menerapkan pengetahuan dan kemampuannya dalam melaksanakan tugastugas pekerjaan yang diembannya. Selain untuk meningkatkan kualitas Sumber Daya Aparatur Pemerintah, menambah ataupun memberikan pengetahuan, sekaligus memperbaiki kinerja PNS agar lebih baik dari sebelumnya.

\section{KESIMPULAN}

Berdasarkan hasil penelitian yang telah dilakukan yakni tentang Pelaksanaan Pendidikan dan Pelatihan Pegawai Aparatur Sipil Negara di Lingkungan Sekretariat Daerah Kota Pekanbaru maka peneliti menarik kesimpulan yaitu:

1. Pelaksanaan Pendidikan dan Pelatihan Metode On The Job Site yang dilakukan di Lingkungan Sekretariat Daerah Kota Pekanbaru Dalam prakteknya digunakan metode Pembekalan, Rotasi Jabatan, Magang dan Penugasan Sementara. Tidak mudah memperoleh pegawai yang berpengalaman dan sulitnya mengatur waktu belajar membuat pelaksanaan diklat Metode On The JobSite kurang maksimal.

2. Pelaksanaan Pendidikan dan Pelatihan Metode Off The Job Site yang dilakukan di Lingkungan Sekretariat Daerah Kota Pekanbaru menggunakan metode Teknik Presentasi Informasi dan Teknik Simulasi. Peserta adakalanya tidak dapat langsung menerapkan pengetahuan atau keterampilan yang diperoleh dari latihan.

3. Adapun faktor-faktor yang menjadi kendala dalam pelaksanaan pendidikan dan pelatihan (Diklat) Pegawai Aparatur Sipil Negara di Lingkungan Sekretariat Daerah Kota Pekanbaru yaitu:

a. Tidak mudah memperoleh pegawai yang berpengalaman dari dalam karena adanya keterbatasan kemampuan atau waktu.

b. Jumlah peserta harus memenuhi rasio yang menguntungkan. 
c. Sulitnya mengatur waktu belajar, artinya banyak hal-hal yang harus dipertimbangkan.

d. pegawai yang berpengalaman (senior) kurang memberikan semangat atau dorongan kepada pegawai baru, sehingga saat pembelajaran dimulai suasana tidak kondusif dan para pegawai cenderung tidak bergairah untuk mengikuti Diklat.

e. Peserta adakalanya tidak dapat langsung menerapkan pengetahuan atau keterampilan yang diperoleh dari latihan.

f. Biaya yang dikeluarkan relatif lebih besar dari biaya apabila latihan itu diselenggarakan sendiri oleh instansi.

\section{SARAN}

Saran yang diberikan penulis dalam masalah penelitian ini utamanya ditujukan kepada instansi Sekretariat Daerah Kota Pekanbaru.Adapun saran yang penulis berikan adalah.

1. Pegawai yang berpengalaman dapat memberikan waktunya untuk memberikan pealtihan kepada pegawai baru agar pelaksanaan diklat dapat berjalan dengan maksimal.

2. Bagi para Aparatur Sipil Negara (ASN) yang telah menjalani Diklat hendaknya langsung menerapkan ilmu yang didapat ketika Diklat agar penyelenggaran pemerintahan dapat berjalan secara efektif dan efisien.

3. Sekretariat Daerah Kota Pekanbaru hendaknya memberikan pendidikan dan pelatihan (Diklat) kepada para pegawai Aparatur Sipil Negara (ASN) secara berkala agar pelaksanaan penyelenggaraan pemerintah dapat berjalan dengan baik dan para ASN dapat bekerja secara professional sesuai bidangnya masing-masing..

\section{DAFTAR PUSTAKA}

[1]. Ambar, T., Sulistiyani \& Rosidah. 2007. Manajemen Sumber Daya Manusia: Konsep, Teori, dan Pengembangan dalam Konteks Organisasi Publik. Graha Ilmu. Yogyakarta.

[2]. Amin, Widjaja Tunggal. 2005. Internal Auditing. Edisi Lima. Yogyakarta: BPFE.

[3]. Arikunto, Suharsimi, 2006. Metode Penelitian: Prosedur Penelitian Suatu Pendekatan Praktik, Rineka Cipta, Jakarta.

[4]. Handoko, T., Hani. 2010. Manajemen Personalia dan Sumber Daya Manusia. Edisi Kedua. BPFE. Yogyakarta..

[5]. Hasan,M,. 2009. Organisasi dan Manajemen. Kaunika. Jakarta

[6]. Ignatius, Wursanto. 2006. Kompetensi Sekretaris. Yogyakarta

[7]. Milkovich, Marthis dan Jackson, John H., 2005.Manajemen Sumber Daya Manusia. Salemba Empat.Jakarta.

[8] Moekijat. 2008. Evaluasi Pelatihan Dalam Rangka Peningkatan Produktivitas. Bandung: Mandar Maju 
[9]. Moenir, H.A.S. 2007. Manajemen Pelayanan Umum Indonesia. Bumi Askara. Jakarta

[10]. Notoatmojo, Soekidjo. 2004. Pengembangan Sumber Daya Manusia. PT. Rineka Cipta.Jakarta.

[11]. Rivai, Veithzal. 2006. Manajemen SDM untuk Perusahaan: Dari Teori ke Praktik.PT Raja Grafindo Persada. Jakarta.

[12]. Rucky, Achmad S. 2007. Penilaian Prestasi Kerja; Teori dan Praktek. PT. Karya Uni Press. Jakarta.

[13]. Sule, E.T, dan Saefullah, K. 2010. Pengantar Manajemen. Edisi 1. Jakarta: Kencana Predana Media Group. ISBN:979-3456-75-1.

[14]. Susilo, S. Martoyo. 2005. Memahami penelitian Kualitatif. Alfabeta. Bandung.

[15]. Sugiyono. 2012. Metode Penelitian Kuantitatif Kualitatif dan R\&D. Bandung: Alfabeta.

[16]. Soeroto,Wahjo., 2005. Kompensasi dan Motivasi. PT. Ghalia Indonesia. Jakarta.

[17]. Soebagio, Atmodiwiro. 2009.Manajemen Training. Balai Pustaka.Jakarta.

[18]. Siswanto, Sastrohadiwiryo. 2006. Manajemen Tenaga Kerja Indonesia. PT. Bumi Aksara.Jakarta.

[19]. Sayuti, Moh. Yakub. 2005. Pengembangan Sumber Daya Manusia. Gaya Media Pratama. Jakarta.

[20]. Simamora,H. 2008. Manajemen Sumber Daya Manusia. STIE YKPN.Yogyakarta.

[21]. Sulistiyani, Ambar Tegun, 2008. Manajemen Sumber Daya Manusia Konsep Teori dan pengembangan dalam konteks Organisasi Publik. Geraha Ilmu. Yogyakarta.

[22]. Simanjuntak, 2005. Manajemen dan Evaluasi Kinerja. Lembaga Penerbit Fakultas Ekonomi Universitas Indonesia: Jakarta.

[23]. Sjafri, Mangkuprawira. 2011. Manajemen Sumber Daya Manusia Strategik. Ghalia Indonesia. Jakarta.

[24]. Iman, Permana. 2015. Hubungan Pendidikan Dan Pelatihan Terhadap Kompetensi Pegawai Dinas Pendidikan Dan Kebudayaan Kabupaten Kampar. Jom FEKON Vol. 2 No. 1. Universitas Riau.

[25]. I Ketut Dartha. 2010. Pengaruh Pendidikan dan Pelatihan (Diklat) Terhadap Kinerja Pegawai Negri Sipil Pada Sekretariat Daerah Kota Malang. Jurnal Ekonomi MODERNISASI Vol. 6, No. 2. Universitas Kanjuruhan Malang.

[26]. Tengku, Annisa. 2015. Pengaruh Pendidikan dan Pelatihan dan Motivasi terhadap Kinerja Pegawai Pada Dinas Koperasi dan Usaha Kecil Menengah Provinsi Riau. Jom FEKON Vol. 2 No. 1. Universitas Riau. 
[27]. Moenir, Sapuan. 2007. Perancangan Penilaian Kinerja Karyawan Berdasarkan Kompetensi Spencerdengan Metode Analytical Hierarchy Process(Studi Kasus di Sub Dinas Pengairan, Dinas Pekerjaan Umum, Kota Probolinggo).Skripsi. Universitas Negri Yogyakarta.

[28]. Siagian,Martha, Monroza. 2008. Pengaruh Pendidikan dan Pelatihan terhadap Kinerja Pegawai Dinas Tenaga Kerja Kota Medan. Skripsi: Universitas Hasanuddin. 